\title{
NEGOTIATING, RESISTING AND (RE)CONSTRUCTING OTHERING
}

The way that young Muslims in Germany identify with Islam or develop a specifically Muslim identity is influenced by how they feel that German society perceives and represents them. In this chapter, I examine the effects of the current Othering of Muslims and Islam in Germany on the everyday experiences of the youth in MJD. I briefly discuss the current German national and public discourse of cultural "Otherness." I subsequently discuss how they actively and creatively deal with these discourses - whether consciously and unconsciously — through the use of tactics (de Certeau 1984). Through this, I seek to understand how the discourse of the "Other" becomes part of the young Muslim women's processes of identity or identification. Yet my contention is that the youth are not passive recipients of discrimination or racism, but that they in various situations also transcend discriminatory or stigmatizing discourses.

In chapter 1, I discussed how the way Muslim youth talk about their decision to be involved in religion is shaped by the dominant discourse about choice. I also reflected on the effects of minority voices not being heard in the public sphere. Here, I examine how Othering discourses also shape the youths' identification processes and, more importantly, how the young women respond to these discourses in multiple ways. In other words, although the youth are clearly not actors who stand outside historical structures, discourses, and limitations, they should not be understood as passive subjects entirely shaped by external processes outside their control. What effects do Othering discourses have on how young women form their identities, and in particular on how they identify with Islam and as Muslims? How do they deal with, or dismantle, the Othering process? And how, if at all, does stigma itself become an integral part of the Islam with which these young women identify?

* The German saying "Stadtluft macht frei" ("City air makes one free") dates to back to the Middle Ages, in particular to the development of town charters that stipulated that anyone (particularly farmers) who lived in a free town for one year and one day would become free from customary rural obligations to lords and community. 
I examine the complex social realities within which the young people I worked with maneuver and the spaces they carve out. This means taking into account specific stereotypes and Othering discourses that frame Muslim youth and Islam in Germany, and asking whether, and if so how, the youth accommodate these discourses. It also means considering how youth use everyday mechanisms of resistance or "tactics" (de Certeau 1984) in these everyday encounters and situations. First, I illustrate the changing constructions of the Other in Germany by pointing to academic research, media reports, and political statements. ${ }^{1}$ Second, I consider the ways in which the young women experience Othering on a daily basis in urban spaces. Third, I point to some of the ways that the young women resist, negotiate, deconstruct, or accommodate the Othering they face in the streets by using various everyday tactics.

Examining how youth resist Othering processes is particularly important, since even if identities must be understood as created within discourse, individuals are not merely called into a social position in the discursive structures (Hall 1996a, 13). It is always important to investigate how individuals defy or refuse to submit to the definitions laid out for them by hegemonic power structures. In the process of refusal, or of resisting the Othering discourses that are used in social interactions, the youth negotiate a "presentation of the self" (Goffman 1959). The various ways the youth resist or adopt stereotypical images of what it means to be a Muslim in Berlin are part of a management of representation. It shows how the young women navigate in public urban space in relation to efforts to interpellate or construct them as Others. Still, as the youth resist or negotiate the Othering discourses, they risk embracing other powerful collective ideas of what it should mean to be a Muslim woman today. By taking up ideals of the Muslim woman, they may well enter positions in which they restrain themselves in order to act and perform ideals of the Muslim woman, thus becoming disciplined bodies. ${ }^{2}$ Is the religious identity of the youth transforming their experiences of the city, in that the city takes on qualities commonly characterized as those of a village, such as social surveillance, social control, and a lack of anonymity?

\footnotetext{
${ }^{1}$ I do not consider this to be an exhaustive study of the construction of Otherness in German society. Yet the material provided here should be sufficient to show that Muslim women are being Othered in Germany.

2 With the term "Muslimwoman" Cooke (2007) has drawn attention to both the recent conflation of gender and religion, and the construction of "Muslim woman" as a primary identity, whether chosen or not, for women of Muslim origins after $9 / 11$. While I am reluctant to use the category "cosmopolitan" identity for Muslim women, I appreciate Cooke's effort to illustrate how women have become a "visual assumption of an Islamic identity" (ibid., 153) while they simultaneously make claims in the public sphere.
} 


\section{The Occidental and Oriental Other}

The notion of the Other is used in various disciplines ranging from philosophy and psychoanalysis to postmodernist theories in anthropology. Though each of the theories are different, most theoretical approaches to Othering are based on the notion that our ideas about who and what Others are (the characteristics assigned, the kind of life they are supposedly living) are closely linked to our ideas of who and what we are (Wilkinson and Kitzinger 1996, 8). There is a general tendency to consider Others to be absolutely and essentially different. This idea of difference enables hierarchical and stereotypical thinking, which is why the effect of Othering resembles racism. An Other is someone who is not compatible with the "mythological norm" (Lorde 1980, 2); that is, she or he diverges from the societal schema of an average woman or man. One consequence of Othering is that a person is viewed as unacceptable when he or she does not meet established socio-cultural and normative standards. ${ }^{3}$

In postcolonial theory, which is my starting point, Othering refers to the discursive production of the Other. This is a process typified by the way in which Europe produces an Orient-as-other (Said 1979), also described as Othering (Spivak 1996 [1985]). Here, I only provide a short overview of the Othering processes in German majority society, while recognizing that some Muslim youth also construct simplified images of non-Muslim Germans. In recent years, scholarship on Occidentalism has cast light on the negative stereotypes which are constructed about the people and cultures of the West in a parallel process to Orientalism. In both Occidentalism and Orientalism, the Other Woman and one's "own" Woman are central, and the former is usually abhorred while the latter is idealized. ${ }^{4}$ Indeed:

\footnotetext{
3 As Zizek, writing about the psycho-social perception of the Other, puts it: "In short what really bothers us about the Other is the peculiar way in which it organizes its enjoyment: precisely the surplus, the 'excess' that pertains to it - the smell of their food, their 'noisy' songs and dances, their strange manners, their attitude to work (in the racist perspective, the Other is either a workaholic stealing our jobs or an idler living on our labor, and it is quite amusing to note the ease with which one passes from reproaching the Other with a refusal to work to reproaching him for the theft of work)" (Zizek 1990, 54). I discuss how the youth construct stereotypical and Othering images of the "German Woman" in chapter 6.

4 The capitalization of "Woman" emphasizes the symbolical conflation of gender, sex and sexuality. Discussing gender within religious systems, Sered (1998) distinguishes between "women" and "Woman." Whereas "women" are female agents who can, to various degrees, claim rights, negotiate, or protest, "Woman" is a symbolic conflation of gender, sex and sexuality. "Woman" comprises allegory, ideology, metaphor, fantasy, and men's psychological projections. The two distinct categories are not necessarily related, meaning that
} 
Occidentalism and Orientalism are thus discourses of power that ultimately serve as mechanisms of control over women in the West and the East; both these discourses of domination use the comparative method of describing women's inferior status in the East or West to convince "native" women that they should be content with the status quo because they are "better off" or superior to "those" women. (Parameswaran 2003, 330)

Positions of superiority are built through misinformed cultural comparisons that construct simplified images. These conflicting positions of superiority redirect the focus away from the parallel processes controlling women in both worlds (Nader 1989).

I do not here discuss how the youth and their Muslim or ethnic communities may construct Othering images of German society and the nonMuslim German Woman, because my main focus is on how the youth respond to the feeling of being Othered in Germany. This is a process that I found to be important to the youth in their daily conversations. For example, Fadwa (23) told some of the young MJD participants and me, "I was opening the car and something fell down, and then a woman passing by was staring at me. I felt like saying 'it's my car.' She was staring as if it wasn't my car, you know." As I show in this chapter, this was not a singular event: similar events occurred weekly.

The youth may respond to Othering processes in the streets that are not produced primarily by the media, but rather relate to their personal experiences as children and while growing up. Additionally, Fadwa's perception of the gaze may well be an extension of her interpretation of the media rather than ill will from the passer-by. I am aware of the ethnographic challenge of how to interpret the gaze. Clearly, sometimes the gaze may be assigned intentions that are not there. Here, I focus on how I understand the youth to perceive the gazes and statements in their discussions and comments about such gazes. Indeed, "[s]mall and trivial racializing incidents with no hateful intentions can still have a negative effect on the people who experience them over and over again" (Gullestad 2004, 185). Likewise, Fanon (1986 [1952]) has famously noted the effect it had on him when a young boy looked at him and said "Look, a Negro!" Before I examine the effects that Othering processes have on the youth,

the experiences of women might not have much to do with Woman. However, within religion these are often conflated. In the theological and mythodological structures in religious traditions, Woman as symbol often plays a profound part, and these structures imprint the lives of the women involved in those traditions, and submit them to the patriarchal structures that often characterize religion. 
I briefly discuss the role of the construction of the Other and the current images of Muslims in German society.

\section{The Role of the Other in Constructing the Nation}

The Othering of Muslim migrants within European nation-states must be understood within the context of nationalism and the extent to which this ideology has dominated the modern European imagination. Kaschuba (2006) calls attention to the eighteenth century cultural identity politics or politics of differentiation, when the European states constructed "das Eigene," (the own) or the Self, through the construction of "des Fremden" (the stranger). The nation developed into an imagined community (Anderson 1983) of solidarity, and developed clear territorial boundaries with political, social, and economic rights as collective goods. The concept of national citizenship is based on increasing ties of dependency linking the individual to the state. The construction of national unity requires the limitation or even elimination of all other loyalties and divisions that are thought to conflict with the idea of a continuous homogenous national population. As Bauman (1990) forcefully argues, subjects are construed as natives by nation states, and uniformity is encouraged. ${ }^{5}$ Those who are thought to deviate in their cultural practices from the norms that are used to define the nation are considered potentially dissident and malfunctioning within the order built by the nation-state, and are expected to adopt the so-called national traits (Anderson 1983).

As will be discussed, in Germany, as in several Western societies, Muslim identities have increasingly come to signify "the Other" after September 11, 2001. This has contributed to Muslims becoming "the victims of discrimination, harassment, racial and religious profiling, and verbal and physical assault" (Peek 2003, 271). Simultaneously, the Muslim as the contemporary Other must also be seen in light of European colonization in the nineteenth century. Edward W. Said examined the phenomenon of Othering and assigned the term "Orientalism" to a style of thought in which the West assigned negative patterns of behavior to the East, which was constructed as inferior compared to the so-called Western superiority. ${ }^{6}$

5 Similarly, Kapfere $(1988,191)$ argues that: "Nations must multiply likeness, not difference, otherwise national identity is weakened."

6 Said has been critiqued, and rightly so, for constructing a too simplistic conception of the colonial reality. Drawing on a Foucauldian notion of discourse, Said contributed to a new understanding of colonialism. Nevertheless, his work on Orientalism promoted a binary thinking, which reified the existence of two rigid entities, the Occident and Orient, 
Said's Orientalism (1979) illustrated how the West constructs representations and portraits of the East as the Other, and how the ideology of Othering is formed through art and literature. The European colonizer, man and woman, writer, politician or traveler, considered Islam to oppress women. The veil or headscarf became the ultimate symbol of Muslim women's allegedly confined and submissive role within colonized societies, and it was argued that the only way to modernize Muslim women and their cultures was through the spread of Christianity and the removal of the veil (Bullock 2007; Fanon 1969). It was thought that:

Short of Christianity, no teaching can elevate the character and position of Muhammedan women in any land; for, as long as she accepts the Koran as a rule of faith, she will unhesitatingly acquiesce in the mutilated life to which she is condemned. (Crawford [1863] quoted in Mabro 1991, 182)

As a strategy to obliterate potential resistance, the French government targeted Algerian women and suggested that they would be emancipated under French rule. Solidarity societies were formed to promote the unveiling of Algerian women (Fanon 1969). ${ }^{7}$ In 1958, public displays of women taking off their veil or headscarf became the ultimate signs of the European role (or duty) of bringing enlightenment and modernity to the colonized countries and of Europe liberating colonized women from colonized men. European women travelers, both secular and Christian, were convinced of the superiority of Western civilization, and urged Muslim women to reform their society by unveiling and refusing polygamy. ${ }^{8}$ In short, the colonial as well as national elites in the colonized societies sought to remove the veil as a way to promote progress, civilize the society, attempt to reveal the harem, and to enhance governmental control over the individual, colonized subject (Bullock 2007; Fanon 1969).

while also largely ignoring discourses in the "Orient." See for example Varisco (2007) for a critical discussion of Said's work.

7 Bullock's analysis of the role of the veil and the impact of the Orientalist viewpoint in colonialist discourses is particularly helpful when trying to understand the contemporary perception of the veil in the West $(2007,1-34)$. She argues that the veil was singled out because it prevented European men from looking at local women, leading to a European male fantasy of the Orient and exotic women. Fantasy versions of the East were presented to Europeans, for example through the inclusion of a Cairo street at the Stockholm World Exhibition in 1889, and several European travelers went to see "the real thing" in the "timeless" space of Egypt, Morocco, or Algeria.

8 For example, the French woman Eugénie le Brun, who was married to an Egyptian man, urged the Egyptian activist Huda Shaarawi (1879-1947) to take off her veil (Badran $1986,80)$. Shaarawi removed her veil publicly in 1923 . 


\section{Migrants Entering the European Nation-State: The Cultural Other}

The immigration to Europe from the 1960s onwards of people who came to be perceived as culturally different Others was increasingly viewed as a threat to the perceived cultural homogeneity of the nation-states. Immigrants were categorized as inherently different outsiders. Clearly, the group(s) that represents the Other within a nation-state is not constant, and the attributes assigned to it and constructed as the problematic differences, are not static. Rather, the content of the difference changes in time and space-closely intertwined with a nations' socio-historical location. In the 1970s, Germany's ultimate Other were Turkish guest workers (Soysal 2003) who, it was thought, seemed to never return where they came from. Family reunification and the increase in asylum seekers between 1975 and 1980 contributed to a feeling of increased competition on the labor market and partly fuelled a fear of foreign infiltration (Überfremdung) through which Germans would become strangers in their own country (Thränhardt 1988). The Heidelberg Manifesto published in 1981 indicates the then latent xenophobic atmosphere: fifteen academics called for protection of the cultural and linguistic purity of the German people (Green 2004). The previous year, theSocialDemocratic Party of Germany(Sozialdemocratische Partei Deutschlands, SPD) Minister-President of Hesse, Holger Börner, pledged during the election that "there will be no more Turks coming to this state as long as I'm in charge" (quoted in Green 2004, 43). ${ }^{9}$ By the end of the 1980s, the Foreigners' Entry Law and a tightening of the rules on family reunification aimed to safeguard the national characteristics of Germany. It was argued that further immigration could lead to the:

abandonment of societal homogeneity, which is primarily determined by membership of the German nation. Germany's common history, heritage, language and culture would lose their unifying and defining nature, the Federal Republic would develop little by little into a multinational and multicultural community, which would over time be weighed down by the resulting problems with its minorities. (BMI 1988, 23, quoted in Green 2004, 61)

The proposed legislation turned out to be controversial and was abandoned. Yet it suggests that whether or not a person has formal citizenship is largely irrelevant to the question of whether that person is perceived as German or not in everyday encounters. Culture and descent are in this respect more important than civil rights and duties. In consequence,

${ }^{9}$ SPD is a left-wing party that originally represented the working class and trade unions. 
invisible social barriers are created in which German citizenship is of little relevance to participation in social life.

In the 1990s, the unification of Germany, the end of the Cold War, and the collapse of Yugoslavia led to an increase in the arrival of ethnic German immigrants (Spätaussiedler) and asylum seekers. ${ }^{10}$ In the same period, extreme right-wing parties were gaining in popularity, and German society was shocked by a series of racially motivated attacks on foreigners in former East Germany (Hoyerswerda and Rostock). ${ }^{11}$ At the end of the 1990s, the president of the German Office for the Protection of the Constitution, Peter Frisch, claimed that Islam would become the largest problem for Germany's domestic security. He also argued that the wearing of headscarves could be read as a sign of how Muslims were consciously excluding themselves from German society (Collet 2004, 121).12 This style of argument would turn out to be typical for future public debates.

\section{Migrants Born in Germany: The Religious Other}

At the end of the 1990s, there was a narrative shift through which the Other moved from being the Turk or guest worker to being the Muslim. This shift in categories was heavily perpetuated through media discourses (Schiffer 2005), German political discourses and policies (Spielhaus 2006), and global events (Allievi 2006). The citizenship examination introduced in Baden-Württemberg in 2006-which has become known as "the Muslim test"-indirectly focuses on a general presumption that Islam and Western democracy are incompatible. ${ }^{13}$ Originally called "discussion

10 Before 1993, the term for "Spätaussiedler" was "Aussiedler." The Federal Expellee Law (Bundesvertriebenengesetz, BVFG) of May 19, 1953, regulates the rights of German refugees or immigrants from Central and Eastern Europe and the definition of who is a Spätaussiedler is found in section 4. Generally, "Aussiedler" are considered to be German because they migrated from Germany in the 1760 (and later) to Russia, Poland, and Romania, sometimes continuing to practice German culture and speak German. During WWII, Stalin sent the German minority to Siberia and Central Asia, as they were considered Hitler's fifth column.

11 A firebombing of Turkish families in Mölln on November 23, 1992 and in Solingen on May 29, 1993, killed eight people in total. See also Green (2004) for a well-researched analysis on the difficulties surrounding reforms of asylum and citizenship legislation in this period.

12 Frisch also asked all Muslims in Germany to send their daughters to school without the headscarf (Collet 2004).

13 As Amir-Moazami (2011) asserts, it is not coincidental that the test was written and introduced in Catholic-oriented Baden-Württemberg. The headscarf debate that centered on Fereschta Ludin (see introduction) also began in the same federal state (Land). The government of Baden-Württemberg was the first to introduce the law banning headscarves for teachers based on the state's constitution and its emphasis on Germany's Christian tradition. 
guidelines," the test is taken in Baden-Württemberg by applicants for German citizenship from 57 Islamic countries (approximately 6o percent of immigrants who apply for citizenship in this federal state) and is supposed to reveal whether the applicant shares "democratic values." Through the test, the representatives of the German bureaucracy are supposed to assess potential new (Muslim) citizens' allegiance to German culture and values, by questioning applicants' political, cultural and social views. Themes include views on religious freedom, equality of the sexes, homosexuality, freedom of expression, the concept of honor, and forced marriage. ${ }^{14}$ It contains 30 questions, including "do you think a woman should obey her husband and that he can beat her if she is disobedient?" "Would you allow your daughter to participate in sports and swimming classes at school?" "What do you think of the fact that parents forcibly marry off their children? Do you think such marriages are compatible with human dignity?" In Germany, the test was referred to as the "Muslim test," as it was obvious from the questions that the initiators of the test presumed that Muslims were the potential new citizens who would oppose what is considered to be the liberal democratic gender regime of Germany.

Researchers argue that German schools reinforce the continuing assumption that Germany has a largely homogeneous population by marking certain citizens or migrants as outsiders in German society. A study led by Mannitz and Schiffauer (2004) compares history teaching and textbooks from France, Germany, the UK, and the Netherlands to see whether and how the construction of Otherness occurs in schools. They argue that in Germany, the idea that students with a Turkish background are Others is reproduced in textbooks. In the construction of the nation, the German people are characterized as "a community of descent and culture" (Mannitz 2004b, 250). History textbooks reproduce the idea that Muslims have come to live "among us," where "us" are Christians. In addition, pupils speaking Turkish in the classroom is perceived as "an expression of 'Otherness," where the pupils(s) is considered to inhabit a cultural niche (Sunier 2004, 153). The youth's foreignness (Fremdheit) is reproduced by the fact that she or he is speaking Turkish. By considering culture to equal mentality, migrants are constructed as Others, and at the same time

14 When introducing the text, Heribert Rech, the Minister of the Interior of BadenWürttemberg, argued that it was based on "publications by authors like Seyran Ates, Necla Kelek, Ayaan Hirsi Ali, and Bassam Tibi [...], according to which in the center of Germany, the human rights of thousands of Islamic women are violated because they are treated like slaves by their families. This can no longer be ignored in the processes of naturalization." Press note, Ministry of the Interior, July 18, 2007. 
an idea of Germanness and Leitkultur (the leading culture or the dominant culture) is upheld although the content of these remains vague. ${ }^{15} \mathrm{In}$ sum, in German schools no (symbolic) space is given to citizens with a Muslim background or to immigrants in the construction of German national identity; instead they are negatively assessed as non-Germans, as Ausländer (foreigner) (Mannitz and Schiffauer 2004).

The media also play a prominent role as mediators in the process of identity formation and Othering processes. The media is a powerful source of referential power, and the identity of the Other is partly shaped by certain signs that the media present and that entail particular ideas of national, ethnic, cultural, or sub-cultural identities. The perception of the Other is further shaped by the readers' interpretation of these signs (Spencer 2006). Although clearly not operating in a vacuum, the media effectively constructs, informs, and authenticates social boundaries in German society. Media studies scholar Sabine Schiffer has suggested that German media frames Islam as Islamism and Terror, and constructs Islam as a form of strangeness (Fremdheit; Schiffer 2005) $\cdot{ }^{16}$ According to Schiffer, a chain of associations, by now unconscious, has been constructed in which Islamism and the oppression of Muslim women are symbolized through the continuous use of references to or images of the headscarf. This representation, she argues, is related to stereotyped, preconceived ways of looking as well as to media perspectives and media's overdetermination of the headscarf (Schiffer 2004; 2008).

Today, German media and several German politicians do not consider "headscarf girls" to be emancipated. Rather, these young women are thought to be reluctant to participate in German society and are constructed as active when considered unwilling to integrate and as passive when viewed as being forced to wear a headscarf by their parents or husband. For German politicians, media, and the majority of the non-religious population, the use of the headscarf (by migrant women) in the public

15 The term "Leitkultur" has been coined by conservative politicians and claims to encompass the essences of German culture. The concept was introduced to the political debate by Friedrich Merz, the leader of the German Christian Democratic Union (Deutschland Christlich Demokratische Union, CDU)/Christian-Social Union (ChristlichSoziale Union, CSU) Fraction in the Bundestag. In an interview with the newspaper Die Welt (October 25, 2000), Merz held that immigrants should adapt to the dominant culture (Leitkultur) of Germany. Leitkultur was later defined as "adherence to the normative values contained in Germany's Basic Law" (Green 2004, 119).

16 "Framing" refers to the social construction of a particular phenomenon by the media, in which the rhetorical approach to a topic advances select interpretations and rejects other interpretations. 
sphere has become a sign of the failure of integration. ${ }^{17}$ The German political (and originally left-leaning) weekly magazine Der Spiegel frequently publishes sensationalist Orientalist front covers with images of veiled or Burqa-wearing Muslim women under headlines such as "The puzzle or mystery of Islam," and, after van Gogh's murder, "Allah's daughters without rights. Muslim women in Germany."18

Here, I provide one example from the German media: under the headline "Prominent German-Turks have called upon Muslims [women] in Germany to take off their headscarf as a sign of their willingness to integrate: those who veil deliberately separate themselves from German society," Ekin Deligöz, Member of the German Federal Parliament (Bundestag) for the Green Party, is quoted as telling (the tabloid newspaper) Bild am Sonntag: "The headscarf is a symbol of the oppression of women. Those who demand that a woman covers her head and hair are making her into a sexual object." The article continues, "Deligöz speaks to Muslim women: 'arrive to today, arrive in Germany. You live here, thus take off the headscarf!' SPD member of the German Federal Parliament, Lale Akgün, criticized the headscarf as discriminatory and called for equality for Muslim women: 'It is unacceptable that a Turkish man can walk in modern clothing in the street - and his wife next to him must wear a nondescript, floorlength coat and a headscarf."'19

Several themes are apparent here. In this article, the idea that a woman can actually choose to wear the headscarf is completely disregarded by the speakers. Instead, the only two reasons why a woman is veiled are because she is forced by external pressures or because she is traditional and not modern. This resembles the colonizing practices in Algeria, where women were asked to remove their headscarves as part of a so-called emancipation and modernity process. Today, the veiled women are not located in (former) colonies, but within Germany. Wearing a headscarf is still

17 The categories "OtherGermans" (AndereDeutsche) or "German-Turks"(Deutschtürken) are sometimes used in the media to categorize identifications not contained in "being German" (Mannitz 2004b, 298). But also "deutsche Ausländer" (German foreigners) or "ausländische Einheimische" (foreign natives) are used in the media.

18 "Rätsel Islam," in Der Spiegel Special, Nr.1/1998 and "Allahs rechtlose Töchter. Muslimische Frauen in Deutschland" in Der Spiegel, Nr. 47, November 15, 2004; my translation. Der Spiegel is not the only magazine engaged in this discourse. Similar stories can be found in, for example, the weekly political and social magazine Stern.

19 My translation from German. Accessed online: Der Spiegel online, www.spiegel.de/ politik/deutschland/o,1518,442656,oo.html, October 15, 2006, accessed October 20, 2006. After the Green Party member of Bundestag, Ekin Deligöz, challenged Muslim women in Germany to remove the headscarf, she received anonymous death-threats. 
considered to be incompatible with being German, or with having really arrived, not just physically, but mentally and spiritually, in German society. In this article, the speaker also produces a particular gender structure within what is imaged as the Muslim family: whereas the man is fashionable, he does not allow his wife to be fashionable, thus victimizing Turkish Muslim women. At the same time, Turkish Muslim men are constructed as oppressors.

The role of the headscarf in the current framing of Othering in Germany is clear: the headscarf has become the ultimate sign of oppressive gender structures. This discursive move constructs veiled women as representatives of gender inequality and as primary signs of the Other. The headscarf has come to symbolize the assumed fundamental differences between East and West. As Göle asserts, "no other symbol than the headscarf reconstructs with such force the 'otherness' of Islam to the West" (Göle 1996, 1). The headscarf is perceived to signal the woman as being out of time and out of place in European societies.

Additionally, the fact that the proponent of this idea was an unveiled woman of Turkish origin adds another dimension: to the German public, she casts herself as the "good migrant" who shows that it is possible to integrate in German society - in sharp contrast to the anonymous veiled women on the street. While the theme of the "good migrant" is interesting and deserves further consideration, in this chapter I look at the "bad migrant": the Muslim woman who has no intention of removing her headscarf. Furthermore, rather than reducing the discussion to how the young women are shaped by the various classifiers (policies, the German school, media, and politicians) that construct her as the Other, I intend to examine how the youth contest some of the stereotyping images. ${ }^{20} \mathrm{My}$ focus in the rest of this chapter is on how the youth deal with these public perceptions of the headscarf.

Islamism has been viewed as a form of collective and political management of Goffmanian "spoiled identity" by several researchers who write about young Muslims in Europe. The idea is that young migrants turn to Islam as a reaction to discrimination and racism. Drawing on Goffman's discussion of stigma, Göle argues that the Islamist movement "turns the 'undesired differentness' of being a Muslim into a voluntary adoption of a stigma symbol that is overtly claimed and offensively communicated in

20 In part, the meaning of the veil or headscarf that is constructed by such media stories exists independently of the reasons given by women for wearing the headscarf, although such media representation may well affect how someone thinks about her headscarf. 
public" (ibid., 16). I agree with Göle that the stigma of Muslimness shapes how the youth identify with Islam and craft a Muslim Self. Still, Göle and other researchers do not analyze the complex processes through which the youth resist or make use of creative tactics to challenge the stigma of being traditional or submissive-which the headscarf is understood to signal in German public space. In other words, how do the Othering discourses in politics and media become socially relevant in women's everyday identification processes? How does the discourse shape the women's social practices in urban spaces? What are the available spaces for maneuvering or for using creative tactics to counter the Othering discourses?

\section{Looking at the Headscarf}

Here, I focus on social interactions in which what the youth perceive as a construction of Muslim women as the Other becomes relevant in everyday face-to-face encounters in the subway, in shops, or on the street. Just as Simmel's stranger is a social form, the Other is not an individual, but a relationship (Tabboni 1995) that is part of a pattern of interaction. The process of Othering takes place in everyday social situations. By looking at these everyday situations, we can identify how Othering processes shape experiences of everyday life and how social actors are not passively subjected to the essentializing Othering processes (see also Bendixsen 2009a). ${ }^{21}$

The processes of Othering that I discuss here have similarities with Althusser's idea of interpellation. Althusser emphasizes how subjects are being constructed and subjected to certain cultural and historical discourses within which they are expected to operate. Althusser's famous example of ideological interpellation is that if a policeman calls out "hey, you," this interpellates the person who is being called as a subject under the law, as the person will turn and recognize this interpellation as referring to him or her. ${ }^{22}$ As will be seen, this resembles the processes of Othering that the youth go through in their everyday urban encounters.

According to Althusser, interpellation takes place through language. What Althusser does not consider, as Butler (1997) eloquently points out, is why the individual accepts the subjectification and normalization

21 As the focus of my research is the perception and life-worlds of Muslim youth, I have not examined how similar situations may affect or impact the notion of "Muslims" among the non-Muslim population. This is a gap in current research.

22 Othering processes resemble interpellation. The interpellated person, according to Althusser, is forced to become the subject that the interpellation is hailing. 
brought into effect by the voice that calls out. Importantly, Butler also asks how the individual can negotiate, redefine, or challenge the conscious or unconscious efforts of interpellation. I discuss some of the tactics that are available to youth when they confront the interpellation or Othering. I argue that how young women use these tactics tells us a great deal about how identification processes take place (Bendixsen 2009a).

During my fieldwork, everyday conversations made it clear to me that the youth were regularly stopped by strangers on the street who asked them whether they were forced to wear the headscarf, or who hurled insulting remarks, such as, "you look stupid with the headscarf", "Taliban!" or "another one of those Mummies." Verbal abuse was a frequent topic of conversation among the young friends, and provoked amusement, frustration, and incredulity. Verbal abuse suggests that people in general consider the young women in this study to be representatives of Islam who have an obligation to respond to questions that are perceived to be related to Islam (be they cultural, social, or political). For example, Sarah (15), whose parents arrived from Turkey in the 1970s, told me:

"The nice thing about the World Cup (was that people were talking to her). Not only about Turkey, but about all Arabic countries, and then slowly the conversation would move to be about terrorism. All of that because of this." She pointed to her headscarf, continuing, "people would say 'I have been to Algeria', and I would say, 'ah, nice, I haven't'." She laughed, and added, "they say that to show me that they know people like me, it is meant to be friendly."

Although Sarah saw the fact that strangers were talking to her as a positive development, the conversation also demonstrates the association strangers made between Sarah and Arabic countries (although Turkey is not an Arabic country) and even terrorism. Sarah considered the development of the conversation to be a direct consequence of her headscarf. Yet, rather than being insulted or feeling Othered, Sarah responded to them jokingly, interpreting their statements as uninformed rather than hostile. When she recounted the episodes to me, she even excused the statements that contain simplified and partly stigmatizing elements, implying that people do not know better. What could have become a series of social situations where Sarah would have felt Othered, she indulged and interpreted as clumsy efforts to be friendly.

Frequently, the young veiled women were treated as non-German and as Others. The relationship between veiling and being perceived as a nonGerman was particularly clear when talking to German converts to Islam: they felt that both the Muslim and non-Muslim population considered 
them to no longer be German once they donned the headscarf. The headscarf seemed to eradicate their Germanness, erasing the fact that they were born in Germany, spoke German fluently, had German grandparents and a German education. Apparently, their religious identification made them incompatible with existing German cultural spaces of belonging. ${ }^{23}$ Those who were born Muslim also felt a difference in how people at large perceived them after they started to veil. For example, Ines (20) believed that when she started to wear the headscarf it changed the way she was perceived by people around her:

Sometimes on the subway, there are like three people sitting across from you, and they stare, look at you like this [she looks at me from head to toe] as if they were in the Zoo and I, like, think, come on hey, stop looking at me like that, as if I am a monkey in a cage! And sometimes you are also imagining it, like, that (you think) they are looking, and then there is maybe no one who is really looking at you, it drives you crazy. (...) And then they ask why foreigners become criminals? Like, imagine, I feel it like that, and I am not even a foreigner, I am German. And they still don't treat me as a German. Imagine how it must feel for a real foreigner, someone who is not a German! (...) I have been German since I was able to think, and now, from the moment when I started to wear a headscarf, I am not German anymore. They treat you differently, you can just feel it.

Ines felt that there was a clear change in how (anonymous) non-Muslims reacted to her and behaved towards her after she started to veil. She personally did not see any contradiction in being German and being veiled, but experienced that she was treated as a foreigner as a result of wearing a headscarf. Growing up in a small German town where she seldom socialized with people with migrant backgrounds, Ines had mostly ethnic German friends before the age of 14. After a turbulent youth, she turned more religious and decided to veil. ${ }^{24}$ Until then, she said, she had no problems considering herself German, a feeling that changed after she visually showed that she is Muslim and the subsequent external reactions towards her. In the above conversation, she particularly emphasized the experiences of being Othered through receiving looks from strangers.

23 Veiled women who insist that they too are German potentially challenge not only who is a German or a European, but also the idea that one must embrace a single identity in order to fit in with the cultural constellations that together make up the nation-state. The idea of trying to be both German and Muslim may well discomfort the nation-state constellation and may be felt as threatening the pureness of the nation-state. However, these claims need to be examined in greater ethnographic detail.

24 I discuss the religious career of Ines in more detail in chapter 7 . 


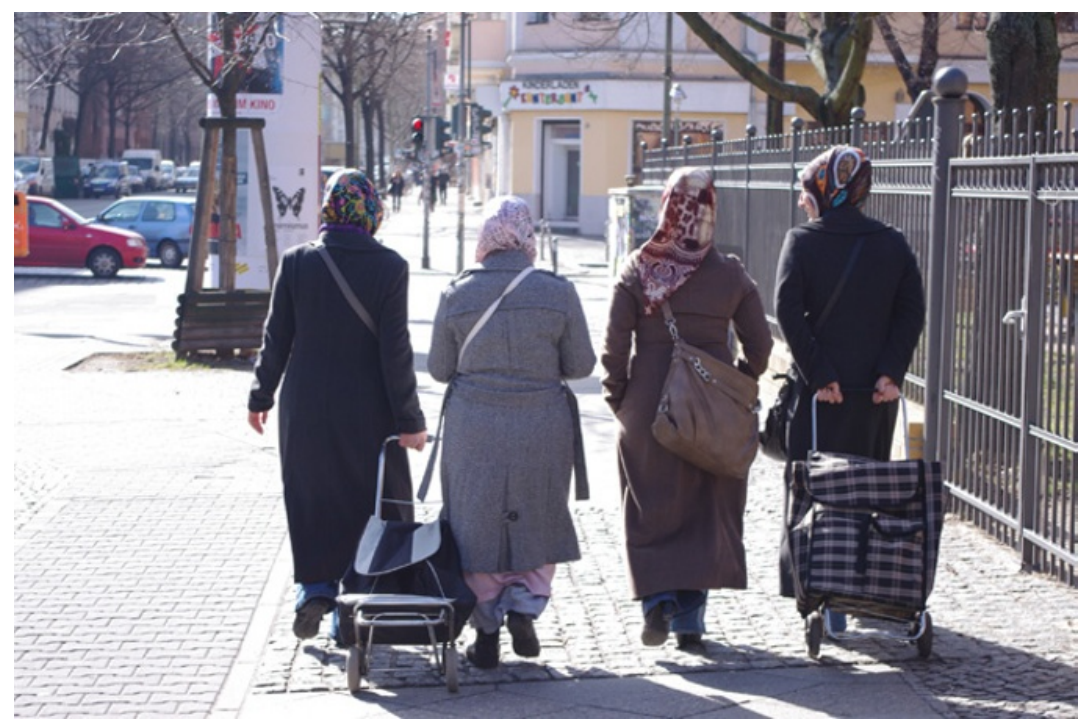

Figure 9. Young women with headscarves, Kreuzberg. Photo: Synnøve Bendixsen.

It was pointed out to me that Othering gazes do not only come from ethnic German non-Muslims, but also from those who were born Muslims or from secular Muslims. Julie (28), a German convert, told me that she sometimes found that she was perceived to represent a political movement, as "the Islamist," "the Extremist," or "the anti-feminist." She interpreted the gazes or negative looks from non-practicing Muslims or "seculars" in terms of their feeling threatened in their emancipation or feeling judged by a "moral apostle with headscarf."

What do (anonymous) gazes do? In his research on medical practices at the end of the sixteenth century, and later in his work on the prison system, Foucault (1995 [1977]) points to how the gaze becomes a technique embedded in power. He points to five operations that the normalizing gaze of modern scientific reason leads to: comparison, differentiation, hierarchization, homogenization, and exclusion. The gaze is not neutral; it has a starting point (ibid., 182-84). ${ }^{25}$ The (anonymous) gazes that the youth feel others them, have social effects that are similar to the normalizing gazes within the state apparatuses Foucault described.

25 The hospital was the first area where the surveillance techniques and the normalizing gaze were introduced. The early schools turned out to be a kind of examining apparatus, where the student is subjected to examination, thus promoting visibility and linking this to knowledge and power (Foucault 1995 [1977], 187). 
Foucault points to how the pursuit of visibility advanced when the examination technique was introduced at the end of the classical age. In this examination technique, the power of an observing hierarchy merges with that of a normalizing judgment. The examination becomes "a normalizing gaze, a surveillance that makes it possible to qualify and to punish. It establishes over individuals a visibility through which one differentiates them and judges them" (ibid., 184). It seems to me that the gaze on the street bring similar operations into play for the young Muslims - namely that of comparison, differentiation, hierarchization, homogenization, and exclusion, where the veiled woman is represented and perceived as a deviation from the norm.

Reflecting upon how the urban represents a space where Othering discourses and normalizing gazes take place does not provide a sufficient understanding of the complexities of these youths' everyday social life and identification processes. ${ }^{26}$ This part of the story only emphasizes the socio-historical constraints and discourses, pointing to the positions to which the young women were (sought) summoned in their lived social experience. A deeper understanding needs to include insight into how the young women identified or did not identify with the positions they were imagined to represent. It must also analyze how they shaped, transformed, created, and performed these positions. ${ }^{27}$ In short, what are the different ways that the young women creatively dealt with the Othering gazes and interpellations on the street?

\section{The Tactics of Muslim Women}

Through my fieldwork, it became clear to me that the young women and teenagers did not unconditionally accept the Othering behavior they

${ }^{26}$ Here I discuss "the gazed upon" and not "the gazer" - thus, I analyze the feelings that the gaze brings into play, and disregard the intention(s) behind the gaze.

27 Although I am inspired by Foucault's theoretical focus on how subjects also form the subject positions, I agree with the critique that Foucault tends to consider the body as being passively inscribed by a subjectifying power (McNay 1991). In her assessment of Foucault's perception of the docile body, McNay (1991) argues that the focal point of Foucault's analysis of the disciplinary techniques is on those in control, largely disregarding those being controlled. This weakness leads to an exaggeration of the efficiency of disciplinary forms of control. In consequence, Foucault falls short of expanding a "notion of resistance" by the subjects of disciplinary power. Foucault contends that oppression always produces resistance: "There are no relations of power without resistances; the latter are all the more real and effective because they are formed right at the point where relations of power are exercised" (Foucault 1980, 142, in McNay 1991, 134). Yet, Foucault's historical 
encountered from strangers in urban situations. Rather, they made use of techniques or tactics to project an alternative self-image that challenged or negotiated the Othering encounter. While these tactics do not necessarily control the encounter, they do shape them. I find de Certeau's and Goffman's concepts useful in explaining the Othering that the youth faced and their reactions or (non)identification with the essentialism in the encounters. The youths' reactions can be considered "techniques of impression management" (Goffman 1959), or as various tactics or strategies (de Certeau 1984). ${ }^{28}$ The term "tactics" refers to acts that are determined by the absence of power, whereas "strategies" are organized by the postulation of power. De Certeau distinguishes them by the types of operations and the role of spaces: "strategies are able to produce, tabulate, and impose these spaces, when those operations take place, whereas tactics can only use, manipulate, and divert these spaces" (ibid., 29). Tactics produce space through frequent maneuvers so as to transform spaces into chances or opportunities. ${ }^{29}$ In daily social situations, people can (re)claim autonomy by using tactics that contest oppressive forces, such as Othering processes. Tactics are everyday practices, for example altering ways of walking, producing, speaking, reading, and dressing, which together can interfere with or confront the prevailing regulatory social system. ${ }^{30}$

Whereas some of the social techniques I want to address here are highly individual, others are learned or practiced within a group. To clarify this point, I provide two examples of individual creative tactics that I noticed during my fieldwork:

studies suggest that the body does not materially resist the processes of power. In Foucault's analysis, power inscribes itself on the body, which remains a passive vector (McNay 1991).

28 To understand how, if at all, the young women take up the external social discourses or interpellations, I make use of a Goffmanian situational analysis. As several researchers have noted (e.g. Calhoun 1994), in the dramaturgical theory of social relations, Goffman describes everyday social encounters and interactions as too intentional, calculating and strategic. I seek to circumvent the radical intentionality that Goffman has rightly been criticized for by drawing on Michel de Certeau's concept of "tactics" (1984) which also recognizes unconscious acts. The distinction de Certeau (1984) makes between a strategy and tactic makes it possible to avoid the models of over-reflexive or rational negotiations of Goffman.

29 In the words of de Certeau: "A strategy assumes a place that can be circumscribed as proper and thus serve as the basis for generating relations with an exterior distinct from it. (...) I call a 'tactic', on the other hand, a calculus which cannot count on a 'proper' (a spatial or institutional location), nor thus on a borderline distinguishing the other as a visible totality. The place of a tactic belongs to the other. (...) A tactic insinuates itself to the other's place, fragmentarily, without taking it over in its entirety, without being able to keep it at a distance" (de Certeau 1984, xix).

30 See also Foucault on tactics (1980, 90; 95), and strategy (1980, 92-95; 1994, 346-348). 
Kiraz (24) told a group of friends about a recent event: She had been sitting on the subway reading Goethe when a woman next to her asked, "are you really reading that?" Kiraz had answered with a playfully invented and feigned foreign accent: "I no German speak" ("Ich keine Deutsch spreche"). As she told us the story she laughed, content with her playful response.

The second event was told at the MJD premises:

After a weekly MJD meeting, Naila (17) told another MJD participant and me a story: as the only veiled woman in a group of female friends, she had entered the department store KaDeWe at Kurfürstendamm. She explained that "they [the other customers and employees] were staring and I said aloud [so that everyone around her could hear] 'you would think that they had never seen anyone with a headscarf before!"”

In the first situation, Kiraz was making fun of the woman, playing with the stereotype that the woman based her question on. In this way, she assumed control of the situation and, disregarding whether her audience understood that Kiraz was making fun of her, dismantled what could have been an experience of Othering. Instead, Kiraz gained a sense of satisfaction. In the second situation, no one confronted Naila directly, but she felt the gazes judge her. So while Naila was not facing anyone in particular, she faced the whole atmosphere, most likely strongly shaped by the particular social setting of KaDeWe, with its exclusive image. If we take a second look at this situation as a scene in a play, with this small performance or reflexive improvisation, Naila turned the situation around, talked back to her audience, and ridiculed and challenged the gazes, at the same time as she confirmed her difference. Yet in this situation, she controlled her own difference.

A performance is intrinsically interactive and risky as it can either (completely or partly) fail or be successful (Schieffelin 1998). Whether or not it is successful depends on the relationship between the different performers in the interaction. It may well be that I only heard about situations which were (partly) successful. However, it is my impression that small performances like these often take the other person(s) by surprise, and the interaction comes to an embarrassed and even confused halt. That said, Ines told me a story that was similar to Kiraz's, but where the confrontation ended differently:

Once I was sitting on the subway reading. I was reading Noam Chomsky and then I noticed that the woman next to me was reading in my book, looking at what I was reading. And so somewhat before my stop, I closed the book so that I would have some time to talk to the woman before I got off, and I put the book on my lap so that she would see the title, and I said, "Noam 
Chomsky" and the title, and then I said, "do you know it? It is very interesting." And the woman said like, "it is very good that you are reading such books." And I did not really understand what she meant, and said that "yes, he is very interesting; he is a Jew, but also defends the Palestinians." And she said, "no, what I mean is that it is very good that you can read." And I didn't want to say something and insult her there on the subway, and just said, "yes [it is important to read]."

The effort Ines made to initiate a conversation with the woman failed, and Ines was taken aback by the woman's response. The woman focused on Ines being able to read German and not on the content of her book. The stranger did not see Ines as a potential partner in an intellectual conversation in the way Ines hoped. Instead, the woman acted condescendingly to a veiled Muslim woman who she thought was fortunate to know how to read. I believe that the difference in the responses that Kiraz and Ines received can partly be explained by the fact that Kiraz was more selfassured, older, and enjoyed telling jokes, while Ines was more timid, quiet, and generally shy. Tactics like these will necessarily be related to personal dispositions, individual characteristics or narrative identity (Taylor 1991), and to the particular context, such as being together with close friendslike in Naila's case.

Not all individuals chose to react: sometimes the youth were confronted with Othering gazes or interpellations too suddenly, and left the situation feeling hurt, not knowing at that very moment how to respond. At the same time, silence can also be a way to question the legitimacy of the authority called upon in the confrontation and by the stranger. It can also be an effort, as Butler, referencing Nietzsche puts it, to "circumscribe a domain of autonomy that cannot or should not be intruded upon by the questioner. As a narrative withheld, it either refuses the relation that the inquirer presupposes or changes that relation so that the one queried refuses the one who queries" (Butler 2005, 12). Silence can thus also be a rejection of what feels like differentiating and hierarchical inquiries, a performance through which the youth may reinstate their self-respect.

The techniques I want to focus on here take place or are learned and practiced within a particular religious social space, namely the MJD youth organization. The tactics mentioned below need to be considered in light of the fact that the members of MJD seek to be perceived as religious or pious, both by themselves and by others (non-Muslims and Muslims). This necessarily affects their self-confidence and the space they make available to themselves for improvisation. I focus on three tactics that the young women mainly used in conversations with or about non-Muslims: 
joking, rehearsal, and normalization. Finally, I examine a fourth tacticcorrective practices - which was used with other Muslims, including strangers and family, friends and acquaintances.

\section{The Joking Tactic}

I found that what I call a "joking tactic" was often used within the group. The joking tactic is characterized by the use of irony, satire, jokes, and wit as a conscious or unconscious means to mediate and overcome prevailing discourses. During their leisure activities like picnics, ice-skating, parties in homes, and during lessons the youth mocked some of the Othering processes and interactions that they faced in the street. For example, amongst themselves, the young women referred to themselves as "terrorists," a "headscarf-band," used the phrase "Scheiß Ausländer" ("damn foreigner"), played with the concept of "modern," and made fun of the Turkish-German accent. The following episode illustrates this well:

At a picnic in Potsdam, we were constantly told by the police in the park that we could not sit here or there. One of the girls finally commented that "they think that we are going to have a picnic and leave everything behind. [Immigrants always act] like that on television." The same day, three of the girls joked about walking in what they called "a group of headscarves": "It was a quiet Sunday in Potsdam. Nobody knew what was going to happen. Perhaps the next minute a bomb would explode...." Everyone laughed.

The playful references suggest that the perceptions others have of their identity also actively constitute it, as others name, categorize, and respond to or treat the youth according to their perceptions of the youths' identities. It is also indicative of the social effect an interpellation or Othering has on its target. Indeed, most "jokes are expressive of the social situations in which they occur" (Douglas 1968, 366). The youths' jokes indicate that they believed that how they were looked upon or treated in a situation or were perceived by non-Muslim strangers in the street had direct links to the representation of migrants in the media. At the same time, by joking with the stereotypes that they knew exist, the young women shared them, took ownership of them, and subverted them. This technique exposes the content of the stereotype, ridicules the meanings, and as such reduces its power when they do encounter such normalizing gazes or utterances from strangers. These types of jokes or utterances worked within this group because the youth had the same semantic points of reference. Simultaneously, such tactics were part of efforts to redefine the content of the "Muslim" category that they were placed in, so that even if they could 
not bring about positive changes in the public view of this category, they could at least label it for themselves in a way that they could control. ${ }^{31}$

\section{The Rehearsal Tactic}

Second, a more direct dealing with Othering processes is what I call a "rehearsal tactic," which took place during the weekly meetings. The women learned how to deal with different situations, and developed a specific kind of knowledge about how to (re)act in public. During the religiously oriented meetings, the leaders sometimes initiated role-plays or workshops on how to best answer some of the most typical questions that the women were confronted with, such as "how do you react if a friend is at your doorstep, and is suddenly not wearing her headscarf?" or for example:

During one weekly meeting, the youth conducted a workshop on "What do you say when someone comes up to you and asks if it isn't hot under the headscarf?" Two participants volunteered to provide their responses. The first, a 19-year-old German convert, answered that, "I tell them that I am proud of my headscarf. That I feel naked without it. That even if it is hot, I wear it with pleasure." The second, Latifa (17), who has a Turkish background, said, "I would tell them that though it is hot here, it is nowhere near as hot as in hell." A discussion followed about what the young women could answer and what would be the best thing to say in such situations.

The confrontational quality of Latifa's answer surprised me, as she had only recently become more religiously active. What does she want to achieve with this answer, I wondered? In addition to her answer partly being a consequence of her recent donning of the headscarf, I also came to realize that while non-Muslims might consider her answer aggressive, for her it emphasized that her decision to wear the headscarf was related to her perception of Paradise and Hell as two realities or spacedimensions that informed her actions and choices. By wearing the headscarf, Latifa believed that she increased her chances of entering Paradise after death. Thus, while it may be an earthly practice which caused some discomfort, this earthy discomfort was nowhere as discomforting as ending up in hell in the afterlife. In contrast, the German convert emphasized

31 The joking and negative reactions of the youth vis-à-vis the public images of "Muslims" in Germany also strongly suggests that these public images do not represent how youth conceive of their own social reality. Whether or not the media stereotypes reflect a reality of the Muslim youth is not relevant, as the youth do not recognize these images as representing their reality. I reiterate that my focus here is on the effect of images that the youth view as negatively stereotyping them. 
what the headscarf provided her with on earth: pride and pleasure, which were parts of her self-confidence as a Muslim woman in Germany. The differences in the two answers show the vast range of potential reactions that various individuals can use.

At another weekly meeting, the MJD group created role-plays about how to best react in particular urban situations:

In introducing the role-play, the leader Fadwa (23) said, "this one is on the subway, we all know this situation." Nawar (17) responded that, "ah, yes, finally at a specific place and also the subway - such an important place." Hamida (17) volunteered and Fadwa gave her instructions: "You are sitting on the subway, and we are non-Muslims and you are yourself." Two of the girls started staring at Hamida, whispering to each other, and continuing to stare [though they were both shy, so they sometimes only laughed]. "Just a second," Hamida said, getting up for her cellphone and putting the headphones in her ears. "I forgot this! I am always listening to music on the subway, so that I don't hear what they are saying." One of the girls said that, "she is doing the right thing." Afterwards, the group discussed how they would react in such a situation, which all the young women recognized.

This sort of role-playing can be understood as a way of practicing how to react and feel more secure in the urban sphere. ${ }^{32}$ MJD represents a safe place where reactions to potentially disruptive or Othering situations can be practiced and improved upon, thus allowing the youth to acquire a certain competence. Practicing how to react also facilitated improvisation and acting in a less conscious manner in similar real situations. The comment that Hamida was "doing the right thing" indicates that ignoring or responding in silence to the gazes or talk can sometimes be the best solution. Through practicing within the group, the women developed a kind of street etiquette; a cultural capital (cf. Bourgois 2003, 135) or a savoir-faire that they could apply in different situations. In this way, MJD participants learned how to be streetwise as Muslim women in Berlin. ${ }^{33}$ Experiences from role-playing simultaneously shaped how the youth interpreted and negotiated the public spaces in which they maneuvered.

32 Goffman argues that practicing is important: "In a performer's acquisition of a particular competence, the first step attempted is often easier and simpler than any he will take in the serious world (...). The first phase of training thus affords the learner some protection from the anxiety produced by incompetent performances..." (Goffman 1974, 64-65). In a similar way to MJD, Jehovah's Witnesses also go through a practice of roleplaying their answers to questions, a fact that Tuomas Martikainen made me aware of.

33 I draw on the term "street-wise" as defined by Anderson (1990). In his ethnography of blacks and whites living in the same American neighborhood, he portrays how they develop ways of the street and learn to maneuver in the urban environment. 
Although many scholars see city life as characterized by anonymity (Simmel 1980 [1903]), forms of social interaction are to a large extent driven by the recognition of clues or imprecise identity markers, including those related to ethnicity, class, occupation, age, and sex. The street operates differently depending on who is there. In fact, this is very much related to the urban conditions where categorization and clues function as an alternative and independent system of public identification (versus, for example, occupational categories) in order to manage street encounters (Hannerz 1980). This also shapes the social performance of social shunning and practices of territorialization (Smith 1984). The qualities associated with these clues vary between societies (Hannerz 1980) and, I would add, within the same societies the meaning can vary over time (Bendixsen 2005).

MJD organizers recognized that social interactions in the street did not take place in an abstract space, but rather in a place entwined with social codes and possible uncertain interactions. They also recognized that social practice is something that can be learned. Knowing how to behave in public is about more than relating to faceless others, or merely accepting the stereotyping gazes or the feeling of being Othered. By learning how to behave in the street within a safe space such as MJD, the youth became skilled at presenting their self-image in public, which is also a form of street capital. This street capital might be a non-translatable cultural capital, but the feeling of mastering situations in the street, which is the aim of this rehearsal tactic, can provide the youth with an increased sense of safety or self-confidence in relation to what they perceive to be normalizing gazes. ${ }^{34}$

Notably, there were never any suggestions about how to act in the former East Berlin, except to avoid that area, or in a worst-case scenario "get in and out quickly." Being streetwise in East Berlin was more a matter of knowing where the border between the former East and West runs and then avoiding the former East Berlin. Such ideas were more related to stories and images of racism and Nazis operating in Eastern areas than to first-hand experiences. The stereotypes that migrants and the second and

${ }^{34}$ During the meeting and discussions, the tactics were mostly focused on daily situations with non-Muslims. A few discussions focused on situations with other Muslims and the "unhealthy habit" of judging too quickly, particularly in relation to the behavior of other Muslim women. It was repeatedly stressed that one should not judge someone's actions without having enough information - that one should first know the context of the action that "seems to be un-Islamic." Social control, including gossip and judgmental rumors, seemed to be an internal problem within the larger Muslim communities in Berlin, a point I return to later. 
third generation had of the former East Berlin constructed spaces as safe or dangerous depending on perceptions of how the people living in these areas responded to those who are perceived to be foreigners or Muslims. Yet, having previously lived in Friedrichhain (former East Berlin), I noticed the increase of veiled women walking in the streets around the vivid café and restaurant life of Warschauerstrasse and Simon Dach strasse from the mid-20oos. Large parts of the neighborhood have been gentrified, and are attracting various businesses such as nightclubs, groceries, and clothing and design stores. Many of these new cafés, restaurants, hairdressers, and hotels are run by Turkish and Kurdish entrepreneurs, although interestingly the waiters or shop assistants are frequently ethnic Germans and the name and interior design of the places are more often than not ethnically non-specific. This suggests a change of perception of some parts of the former East Berlin among persons with a migrant background. In the longer run, this might also change the negative assessment of this area among the larger population with migrant backgrounds.

The emphasis MJD placed on practicing forms of self-presentation as spatial tactics fits well with what seemed to be an underlying aspiration for the organization, namely assisting youth in becoming self-confident Muslims who know how to perform and talk about Islam in the German public sphere. ${ }^{35}$ During the meetings, this micropolitics about street communication took different forms, including reminders to smile to other women with headscarves, or to make references to messages in the Koran, or a hadith, in everyday situations. For example, one of the organizers, Leila (21) gave a presentation, in which she said:

\begin{abstract}
"When we are sitting on the subway and there are no other Muslims there, we feel like an outsider and do not dare to take out the Koran to read. Why are we ashamed to do that? People are looking anyways." Leila then refered to a verse in the Koran and a story from the life of Muhammad where the moral is that one should be proud to be who one is, including in front of other people. She asked, "what did Umar Ibn al-Khattab [the second Caliph] do when he took up [converted to] Islam or what did a young man do at a university-praying in the middle of the university? When everyone is doing this, there is a [positive] chain reaction. Trust yourself. Just do it". ${ }^{36}$
\end{abstract}

The negative looks that someone reading the Koran on the Berlin subway may receive, might equally well happen to those reading the Bible, thus the gazes might be a reaction towards the religious act and not specifically

\footnotetext{
35 It is also a form of identity politics that I discuss more in chapter 7 .

36 Notice here the similarity to the Nike commercial "Just do it."
} 
towards Islam. Yet the youth interpreted such situations as targeting Islam exclusively. In this conversation, Leila made a direct link between historical time and today: born in the year 580 , Umar converted the same day that he planned to assassinate Muhammad, and later became the second Caliph (634-644). His conversion made Muslims more confident in practicing Islam openly, as nobody dared to obstruct Umar's prayer at the Ka'ba (Islam's central house of worship, located in Mecca). The women in MJD were also encouraged to be self-confident and to not be ashamed of openly practicing Islam through a (direct or indirect) emphasis on their being part of the larger Muslim society (the umma). Their daring to perform their religious practices openly in the street was perceived to potentially inspire other Muslims to perform their religion openly. Openly professing one's religion can be a form of $d a^{\prime} w a$, which means "call" or "invitation" in Arabic and is an invitation to Islam (not unlike the Christian notion of evangelizing). Thus, the religious dimension cannot be omitted here. It forms part of the emphasis within the youth group that it is normal to be a practicing Muslim and that this should be the starting point of an effort to take Islam into the public sphere and make it common.

As mentioned, negative reactions towards displays of religion in Berlin may potentially be less directed towards Islam per se, and rather target religion in general. Expressing religiousness openly in what is typically viewed as a secular-minded city might provoke different reactions compared to cities in the south of Germany, where religion plays a more notable part of people's everyday life (for example in the common form of greeting). One can therefore question to what extent any public display of religiosity by youth would provoke negative reactions, regardless of whether they were practicing Islam or any other religion. ${ }^{37}$

While this is a question that remains to be answered, in the particular case of these women, the visibility of their practicing of Islam became a feature of their struggle for recognition. For them, the visibility of their religiosity could become a source of power, and the invisibility or suppression of the visible act could in turn be seen as a sign of subjugation (see Fraser 1999, 119). This struggle for recognition can be seen in the following $d u^{\prime} a$, which concluded one of the weekly meetings: 38

37 Thus, the extent to which the Othering of the Muslim women should be understood only as a consequence of their being Muslims specifically, rather than more generally being religious in a society where religion is supposed to be confined to the private sphere, remains a question open to investigation.

38 In addition to the five daily ritual prayers, different $d u^{\prime} a$ prayers are performed, for example when undertaking a journey, or before and after a meal, or when ending a 
Ya Allah, help us to be active... Allah, help us to be self-aware so that we can walk the street without people being able to do what they want with us. Ya Allah, help us to improve our knowledge of Islam, so that we can answer questions well.

The tactic of rehearsing forms of self-presentation can also be understood as a way to challenge the content or representation of Muslim women in German society in general. This is a struggle over meaning or a "politics of the image" (Hall 1997); a contestation of what is represented in the media, which fixes the meanings attached to Muslims. These struggles for "recognition of difference" (Fraser 2000) are efforts to challenge the stigmatizing gazes or media representations. It suggests that people who are constructed as deviant have the opportunity to strategically challenge the stigma and to fill their category or representation with positive content. ${ }^{39}$

Learning how best to react can also be understood as practicing da'wa. This group of women saw it as their religious obligation to improve, correct, or renegotiate the stereotyped image of Muslims in Germany so that more people would be attracted to Islam. The women sought to make people appreciate their religion by showing good behavior. Everyday micro-politics that the young women performed, such as being especially helpful or practicing how best to answer questions about Islam, are indicative of how Othering discourses shaped their identification process and daily activities, but also of the potential techniques available to counter the discourses.

\section{The Normalization Tactic}

A third tactic is to emphasize normality. I was alerted to this intentional and conscious tactic by Julie, a German convert. Julie (28) told me that she sometimes attempted to accentuate normal or unexpected behavior to break the wall of Othering and thus strived to make the headscarf be of no importance or forgotten in the situation. Signaling that "I am normal, I am like you," is an effort to neutralize the starting point of the situation.

meeting. In the Berlin MJD, the youth always performed a du'a to end the weekly meetings. In MJD, it took the form of a combination of ritual words in Arabic, and more personal phrases in German. This was sometimes performed by all of the participants contributing one sentence each, sometimes by one youth alone.

39 Although the process is different it is worth mentioning the early civil rights movement's strategy to change the connotation of the sign "black" from "Black = despised", to "Black = beautiful.' See also Göle (1996) for a discussion of Islamist movements as social movements, a process that asserts that "Islam is beautiful" $\left(1996,15^{-18}\right)$. 
This can also be illustrated by Fatima (31) who, while in DMK one Friday evening, suddenly asked me:

“Do you know Pippi Longstocking?" I said that I did. Fatima continued, "I sometimes tell them [the Germans], that I also grew up with Pippi Longstocking, you know. I grew up here and have seen the same the children's shows and have the same childhood memories as them. I was born here! They don't realize it. They see my headscarf, and don't understand that I have grown up here as well, just like them."

This practice is an effort to actively establish common points of biography with people in her generation who do not consider themselves to have any biographical similarities with Fatima, since she is Muslim. ${ }^{40}$ Another relevant question that is brought to light here, is who has the right to decide when being a Muslim woman should be relevant. By pointing to Pippi, Fatima insists that being German/Western and Muslim is not a contradiction. She also indirectly asserts that her religious identity is not always the most relevant aspect of her life story in a social interaction. With her emphasis on common children's television programs, she tries to construct a common frame of reference with Germans who are not Muslim.

German converts often took this translation work particularly seriously. For example, the German convert Margit (24) told a story to other mosque participants about a time she was in a doctor's waiting room:

They came out and asked for Margit Heinrich, and looked at everyone, except me. When I said, "that's me," they looked at me, and then checked my identity card to see the name. [She is wearing a headscarf in her passport photo]. Many converts take on a Muslim name when they become Muslims. But I wanted to keep my German name so that they can see that it is not only foreigners who are Muslims. There are also [Muslim] Germans, more and more.

Similar practices that assert "normality" include awareness of types of clothing and the use of colors. Some women very consciously did not wear black during interviews or in public discussions because they believed that black could present a negative image or impression of fear vis-à-vis non-Muslims. ${ }^{41}$ For example, on the day before sitting an examination,

40 One of the reasons that she mentioned this popular Swedish children books and television series from the late 1970s can be related to my long red hair, which is similar to Pippi Longstocking's, and that I am from Scandinavia. It may also be because most Germans know and enjoy this program.

41 Göle $(1996,84)$ argues that in Turkey, the black veil symbolizes the "return to premodern Islamic traditions" and that it "acted as an expression of the active participation of women in political demonstrations." 
Rüya (21) discussed with Jenny (26) and Fadwa (23) whether her dress style "looks too extreme." She explained that she was wondering whether she could dress like this for her examination and what her examiners would think of her. Rüya was wearing an ankle-length skirt in dark blue that had no ethnic or national associations. Jenny said that maybe she did look too fundamentalist and Fadwa suggested that Rüya wear a long shirt instead of a skirt.

Such discussions and reflections on their outer appearance suggest that the youth also adapted to the media images and discourses in their everyday social practices. For many, wearing a headscarf that matched the overall outfit was not only about personal taste. Rather, it was a matter of signaling that they were not fundamentalist or oppressed, in contrast to what the media and politicians suggested. Their matching dress is intended to show that they are modern, fashionable, and at the same time wear the headscarf. Yet while the youth tried to reverse some stereotypical images, they reinforced and adapted to others. For example, the youth displayed stereotypical images of other Muslims in Berlin, for instance about those belonging to what the youth considered more traditional and ethnic versions of Islam. At one point, Ines told me that she did not feel like going to a Kurdish wedding since, she claimed, these weddings usually ended in fighting. She explained that there were always some youth who were not "really Muslims" and that the fight would start when someone looks at their women or throws a bottle. Ines here viewed an ethnic group as more likely to become violent at a celebration, referring to stereotypical views about gender relations within a specific ethnic group. Moreover, she believed that not all of them were "real Muslims," although culturally they were Muslims, and she believed that this in turn increased the chances that a fight would take place during the event. Though non-Muslims generally do not distinguish between"real Muslims" and "cultural Muslims," these youth tended to explain social problems and unwanted behavior within specific ethnic and national groups in terms of a failure to understand Islam or un-Islamic behavior.

\section{Politics of Representation}

The effort to present an ideal or improve the image of Islam in the public sphere increases the pressure on the youngsters within a religious team. "Team" is here defined as "any set of individuals who co-operate in staging a single routine" (Goffman 1959, 79). In his work on stigma, Goffman (1963) 
contends that the burden of idealized conduct can be found in particular among marginalized individuals. Their deviance may compel them into "discredited" or "discreditable" groups, founded on the character of their stigma (Goffman 1963, 42). Managing the impression they make becomes more important among these individuals because, being discredited, they often try to tone down the tension their stigma causes in order to produce a more successful interaction with others. Inadequate social interaction leads to feelings of ambivalence and alienation for the discreditable person who struggles to pass and utilizes disidentifiers in order to establish her or himself as normal. Emphasizing an idealized, normative identity and behavior in order to gain recognition from the larger population simultaneously limits the discredited person's capacity for interaction. Thus, when a person has to struggle with a stigma of any type, this will change the nature of their impression management and, therefore, their interactions with others change. ${ }^{42}$ This is particularly the case when one identifies with a group that is marginalized and discredited. The need to present a genuine, self-affirming collective identity may well involve a moral pressure on individual group members to perform in relation to a specific group culture. A dissident may be viewed as disloyal towards the effort of building up a positive group image. ${ }^{43}$ How does the fact that the youth belong to a discredited larger group of Muslims, and identify with the smaller MJD faith community, affect their public appearance and self-projection?

These youth were highly conscious of stereotypes and partly understood how these affected their daily lives. Both the Othering discourses and the tactics the youth practiced are gendered processes. Women who are defined as belonging to minority groups frequently struggle with this catch-22 dilemma: they derive self-realization and strength from their collective identity that enables them to oppose stereotypes or normalizing systems, but by adhering to a collective identity, they simultaneously risk

42 Alberoni (1984) points out that in the nascent state, the process of restructuring fields of experiences to new ends is the foundation for a shared affinity among the participants as well as that which mark their distinction.

${ }^{43}$ Likewise, Fraser directs our attention to the moral pressure on individual participants in the effort the group makes to present a genuine, self-confirming group identity (Fraser 2000, 112). She asserts: "Stressing the need to elaborate and display an authentic, self-affirming and self-generated collective identity, it puts moral pressure on individual members to conform to a given group culture. Cultural dissidence and experimentation are accordingly discouraged, when they are not simply equated with disloyalty" (ibid.). This is remarkably close to Goffman's arguments about the pressures that exist when identifying with a group. 
undermining their own room for action. In other words, minority women tend to try to defend their collective group against discrimination and subjugation, but in doing so they risk setting themselves up as representatives of the symbolic "Woman". The effort to defend their group, or to bring about a self-affirming collective identity, may bring with it restraining or repressive aspects (see Yuval-Davis 1992, 224) in view of their social position (as Woman) within the group. Indeed, the ambition to make an idealized impression on their observers (Goffman 1959, 35) leads to individual and peer pressure on the young women and their public behavior. ${ }^{44}$ One consequence of this is that youth who emphasize the need to correct negative stereotypes among the non-Muslim population try to modify other young women's public behavior through peer pressure in order to get other youth to conform to specific behaviors.

This limits the space a young woman has for individual selfunderstanding, since instead of soul-searching she sets herself up as an ambassador for a wider identity she cannot herself control. Selma (19), an unveiled woman I interviewed, had decided not to veil because, she said:

I don't look very Muslim! Like, look at the way I dress, with short skirts and such, and also my behavior is not always that Islamic. You know, when you are wearing the headscarf you are representing Islam in the street, it's a responsibility that I don't know whether I am ready for.

Selma's comment illustrates the relationship between internal (she is Muslim) and external (not looking or performing as a Muslim) aspects of being a Muslim. My main point is that Selma felt that there were external expectations about veiled women in the urban space. She believed that a decision to veil was not only a personal choice, which an individual could take either on her own or with input from her family; rather, she believed that such a decision would also bring with it certain representational obligations that Selma did not know whether she was ready to take on. This shows the tension between the strength the young person may acquire from veiling and the additional limitations and peer pressure she will have to accept as a consequence of wearing a headscarf. For many of the Muslim women who seek to live a pious life, this religious path does not only mean following the religious norms and practices. It also means living up to

44 This may also be viewed as the acting out of a "performative reflexivity," "a condition in which a sociocultural group, or its most perceptive members acting representatively, turn, bend, or reflect back upon themselves, upon the relations, actions, symbols, meanings, and codes, roles, statuses, social structures, ethical and legal rules, and other sociocultural components which make up their public 'selves"' (Turner 1986, 24). 
certain expectations in the public sphere, as being perceived as a Muslim woman comes with a variety of expectations regarding their social behavior, both from Muslims and non-Muslims - although in different ways. The silent expectations and concrete social reactions from Muslims are illustrated in the following story from Noreen (16):

My father has seen sisters with headscarves together with brothers. They were not married, but were holding hands in the street. It made him so sad. In the next speech [in a mosque] he said to the brother and the parents that this is not right - when it is like that they should rather marry. If they do that [holding hands], they are probably ready for marriage. And if they do not dare to go and talk with the father of the girl, then they should come to him and he would go with them.

Here, Noreen is expressing pride in her father, although this might be more to do with the role her father played within the religious communities than his views about gender relations. More importantly, her comment shows that religious authorities reflect on what goes on in the street, and try to correct within a religious field what they perceive to be incorrect behavior, in this case through a talk in a mosque. The social pressure and consequent feeling of community policing (Dwyer 200o) cannot be underestimated. Through such social interactions, the performance of one's identification (i.e. with gender, Islam, or both) is guided and partly structured. It also suggests how, according to Althusser, as a consequence of an interpellation (the "summoning into place") in a social situation, the person in focus (the interpellated person) is becoming the subject of the interpellation. However, this line of argumentation neglects the negotiations or tactics that social actors can make use of, leading me to a fourth tactic that I call a "corrective tactic."

\section{The Corrective Tactics}

The corrective tactics were mostly directed towards Muslims-both known and unknown-who know which acts are generally considered acceptable or correct in Islam. Corrective tactics focus on paying conspicuous attention to how particular acts appear to other Muslims. These tactics can be used both to conceal acts which otherwise would be frowned upon, or to preserve appearances where an act would be (considered) religiously correct, but which could be misunderstood as not correct. For example, during a wedding celebration Aishegül (31) told me that:

My little brother is here, and I wanted to hug him, but then I couldn't because the [Muslim] brothers were there and they might not know that he is my 
brother, and think that we are married. Or they know that I am not married, and wonder what am I doing? And so instead I squished his hand like that, and then there was a German brother who saw it.

To not risk that people misunderstood her action (in case they did not know that he was her brother), Aishegül abstained from hugging her brother. As Aishegül was seeking a husband, it would have been unfortunate if men believed that she was married. Moreover, it could give her a negative reputation within the religious and ethnic social sphere should there be rumors that she hugged a man (who not everyone knew to be her brother) in public. Being religiously knowledgeable and virtuous can constitute symbolic (and cultural) capital, which is important with regard to marriage, when the families make inquiries regarding a potential husband or wife within their social spheres. Thus, to appear to behave correctly when in public becomes important in order to not damage one's reputation.

Concern for appearances can also make youth modify their actions in cases where they know they are actually breaching religious norms in the public sphere. For example, when friends and I left Rüya (21) alone with her future fiancé in a restaurant, she later explained that she borrowed her sister's ring so that it would look as if she and her future fiancé were married. Such a corrective practice is employed to "safeguard the impression fostered by an individual during his presence before others" (Goffman 1959, 13); here towards other unknown Muslims, since those acquainted with her knew she was not married, and non-Muslims would not care. ${ }^{45}$

Both the corrective and the rehearsal tactics are ways of performing within an impression management context that can be considered a dramaturgical discipline (Goffman 1959, 216). "Dramaturgical discipline" can be understood as the necessity for every individual associated with a group to make individual efforts to maintain or improve the performance of the group's external image in order to maintain group coherence. In the process of improving the Muslim image in Germany, the young women risk becoming self-regulating subjects in a Foucauldian sense, and to turn into self-observing subjects. ${ }^{46}$ The corrective and rehearsal tactics partly

45 This is also a creative form of agency: an action that conforms to norms appropriate to the situation can also entail new and unfamiliar paths of actions (Joas 1996, 233).

46 Discipline, as Foucault (1995 [1977]) has illustrated, is not externally imposed but rather is performed internally; discipline does not function at the level of the entire society but at the level of detail, and not by forcing or restraining individuals and their acts but by producing them. 
uphold or frame a particular image of the Muslim Self to others and oneself, and partly circumvent negative sanctions from ethnic and religious social fields in which performing in a non-normative manner risks regulative punishment-which in this particular community may take the form of a getting a bad reputation.

\section{The Headscarf as Social Capital}

Thus far, I have focused on situations where the women felt that they were being Othered or felt interpellated. I want to briefly discuss situations that did not start from the point of the Othering discourses, but where being a Muslim woman was a form of symbolic capital or a resource. There were certain moments or interactions where wearing the headscarf felt advantageous or where spaces were translated into ethnoscapes (Appadurai 1996). ${ }^{47}$ In a discussion about Othering, Julie emphasized that she also experienced positive reactions on the street, including admiration and comments from other Muslims:

She recalled comments from other (unveiled) Muslims who told her that "I also want to wear the headscarf at one point." "As a veiled woman in the street," Julie argued, "one can also be perceived as a moral role model; everything that someone-whether male or female-morally, spiritually or religiously has not (yet) achieved is projected onto the women."

The headscarf can help present the women as positive and important Others for other (non-veiled) Muslims. Julie added that she sometimes met particularly encouraging and friendly non-Muslim faces in the street, something that for her may have indicated a certain solidarity with the stigmatized. ${ }^{48}$

Being religious and having a migration background can be turned into relevant experiences for some positions or jobs. In some exceptional cases, veiled young people are preferred as employees, either because a shop owner wants to portray a religious image or because she or he personally

47 By "ethnoscape," Appadurai $(1996,33)$ means "the landscape of persons who constitute the shifting world in which we live: tourists, immigrants, refugees, exiles, guest workers, and other moving groups and individuals constitute an essential feature of the world and appear to affect the politics of (and between) nations to a hitherto unprecedented degree." With this concept, Appadurai draws our attention to how the reproduction of group identities is changing socially, territorially and culturally as a consequence of migration and a regrouping in new locations (ibid., 48).

48 Similarly, in her research on Turkish migrants in Germany, Nökel has pointed out that " $[t]$ o be successful despite wearing a headscarf is the ultimate sign of personal recognition and personal identity politics, different from simply assimilating" (Nökel 2006, 430). 
prefers her or his employees to be veiled. When Ines decided that she wanted to become a social worker and tried to enter an Evangelical School for this program, she told me:

There are not many Muslims doing social work, or there are some, but they don't bring their religion with them in their work, 'cause they don't practice it, or they don't know how to pass on their religion correctly. Like when the children ask about it, they should be given the right answer and not the wrong answer. And it's important. You know why? 'Cause when you say where you come from, you are talking about belonging, and like, when you ask me who I am, I don't really know. Like I am not German, I am not Lebanese, and I am not Palestinian. I don't know where I come from. Like, it's important to look where your parents come from, to know the culture, the history and such. I don't know my own language well; I have not been raised with it. (...) Like, my parents thought it was important for me to be integrated here, and that is why I have a German name and such. But I still miss something. Like, that is why you have these young criminals and such; they have problems, 'cause they don't know where they belong. (...) I said this at [the interview for] the Evangelical school - I said that it is important and she said that she would write very positively about me. I am so excited.

Here, Ines emphasizes her migration background, which became a motivational factor for her choice of education and future employment. ${ }^{49}$ The way she was raised is also brought to the fore as a main reason that she felt somewhat out of place in Germany. She felt that using religious knowledge as well as her personal experience of growing up as a migrant was important when interacting with immigrant youth. Ines sought not so much to become a role model for immigrant youth, but to draw on her experiences in order to assist troubled immigrant youth. In this work, her goal was to create spaces of belonging in Germany for the youth that she herself was missing.

Many of Ines's friends who also wore headscarves asked her whether it would not be difficult to be accepted by a Christian school. Ines argued that on the contrary, they paid attention to her voluntary work and her personal intentions during the interview. Ines was accepted by the school and turned out to be the only one wearing a headscarf at the school, which

49 Karakaşoğlu (1999) suggests that several second-generation Muslims with Turkish backgrounds would like to be teachers, a career in which they can use their traumas constructively. She found that several intend to provide assistance for the coming migrant generation in the German educational system through their particular knowledge and institutional and life experiences. Many feel an obligation to be role models for migrant youth and to show the majority non-Muslim society that they can participate in the dominant society. 
is located in former East Berlin. For a long time she had difficulties finding friends, something that changed once she got back her first homework, for which she used her knowledge of Islam and got a top grade. Subsequently, the other students started to talk with her and wanted to work with her. She realized afterwards that they "were afraid" and did not know how to talk to her. She explained that "before they considered me to be different. After all, I am different!" Thus, while she was able to turn her religiousness (it was an Evangelical school) and her migrant background into a form of symbolic capital or resource during the admission process to the social work program, she gained acceptance from the other students through her intelligence and academic success. ${ }^{50}$

\section{Contesting Representations}

The young women identified with a group (MJD) that is conscious of the ruined image of Muslims and that emphasizes the role of Muslim women. This made the youth feel that it was a religious duty to negotiate and change the negative stereotypes of Islam of which the Othering is a symptom. The youth were highly aware of the viewpoints and opinions about Muslims and Islam in the wider German society; such views are clearly expressed by the media and politicians. The religious social field is deeply informed by German public discourses about its Muslim population, discourses that are situated in a specific historical and social context. At times, the youth and group leaders also accommodated these Othering images. Simultaneously, the teenagers and young women can manipulate or transform events to turn them into spaces of resistance or negotiation, and thus reject a passive discursive construction or interpellation of themselves as predefined Muslim subjects. ${ }^{51}$

What are the consequences of the tactics that reply to the perception of the Other to which the women I worked with respond? Will the woman on the subway change the ideas she has of Muslim women in one way or the other after her meeting with Kiraz? Does it represent a new experience for

50 It is noticeable that in this instance, Ines drew on her knowledge of Islam in her school work. Most of the time, such knowledge is a symbolic capital within the religious (and ethnic) social field. This is one of the few instances I have seen where a young person converted their religious knowledge into symbolic capital outside of the religious or ethnic social field.

51 Clearly, the reactions of the youth may also be about playfulness as it can be fun to play against stereotypes. By provoking reactions and then responding to them, one may feel confrontational which, among other things, reduces the feeling of being a "victim." Nevertheless, in the political climate such an individual playfulness is intertwined with a group-oriented struggle to define what Islam is. 
her and will she consequently test and modify her knowledge through this situation? The identity a person seeks to communicate must be accepted by her or his social environment and socially relevant others (Barth 1969; 1981). Zizek (1991) reminds us that the subject can never completely control how she or he appears or incite changes in others. Few actors have complete power over how the other person in a social interaction will interpret and reflect on their impressions of them. Additionally, unequal power relations permeate any micro-interaction. Unfortunately, thus far there have been few studies done on the (potential) changes in the majority perception of the Other.

What I have called attention to here is the use of tactics to resist Othering discourses and the impact of such experiences and interactions on the young women I worked with, particularly in relation to how the women present themselves. The impression management efforts I have described illustrate the performative aspect of a religious identity, which is embedded in social practices. Tactics can also lead the actors to identify "new positions from which to act" (Strathern 1988, 320) as they develop a micro-politics related to the stigmatizing Othering they encounter in daily interactions. Youth are not merely passively receiving or submitting to the negative discourses or stereotypes. Rather, at the experiential level the youth challenge, subvert, and even partly transform the stereotypes or discriminatory practices.

The discourses of Islam that the youth relate to in crafting their religious Selves make them part of a group-oriented struggle to improve the current negative perception of Muslims. To some extent, youth who veil are searching for a differentiation, which in turn is confirmed by the normalizing gazes. It is the judgment and its hierarchical effect that the youth contest, reject, and seek to alter. The normalizing judgment the veiled youth face brings with it an assignment of specific attributes, such as being submissive, oppressed, traditional, and the ultimate Other. The ongoing stereotyping and homogenization situate all women with headscarves as representatives of "Muslims," a category that the youth view as in Germany taken to mean potential terrorists, non-Germans, and products of a "traditional" immigrant culture.

In this process, youth take part in a struggle for a "recognition of difference" (Fraser 2000), which is part of identity politics. The starting point of any identity politics is representation (Brunt 1998, 152).52

52 Brunt argues that there are two questions that need to be asked in relation to representation. One, "how are identities represented in and through culture, and assigned 
By "representation" I refer to the efforts to change the negative stereotypes and categorizations; to alter what "Muslim" means in the German public sphere. In this public struggle of representation, MJD and its participants become, or strive to become, part of a struggle to define what and who is a Muslim. Seeing representation as a collective struggle recognizes that members of a group are joined together, both by means of a general understanding of the past as a narrative of discrimination and as a felt necessity to overcome the historically destructive social meanings advanced by such a narrative (Williams 2000, 181). Identification with a faith community situates the individual within a larger community of Muslims. This involves reflecting on being part of a "Muslim" category, or even community, which also entails a feeling of having to represent this category to Muslims and non-Muslims alike.

These tactics to deal with a lack of confidence through training and improvisation can also be considered to be practices of resistance. Resistance questions the constituted order by putting it on trial or by insisting that it should be put on trial. The reactions of the young women are sometimes informed by their past experiences and are sometimes improvised. The process by which a young woman learns how to react during the weekly meetings becomes part of the crafting of the youth as Muslims living in Berlin. These tactics also open up for notions of changes in habitus. ${ }^{53}$

As urban actors, young women rehearse, learn, or improvise a variety of tactics to perform in their encounters with strangers, in part to gain more control over the situation and consequently potentially shape it. Both the young women and the strangers may reinforce existing stereotypes, or develop new ones. In the long run, the young generation may establish new social patterns and norms of tolerance, thus encouraging a daily ordinary civility, if not social harmony. Tactics like these interrupt, disturb, and prevent the individual from being placed in a position in which they are subjectified by Othering discourses. Subjects are clearly formed by interpellations or Othering, but cannot be reduced to their submission to these; rather there are moments and movements of autonomy and creative acts,

particular categories", and two, "who or what politically represents us, speaks and acts on our behalf" (Brunt 1989, 152). The latter refers to community representation and the problem that one "representative" represents people of very different categories with sometimes conflicting experiences but have in common that they are "disadvantaged."

53 Habitus is an arrangement of acquired patterns of thought, behavior, and taste. It is the link between social practices (or action) and social structure (Bourdieu 2004 [1977]). I discuss habitus further in chapter 6. 
through which the young women emerge transformed. In this process, youth are starting to play the role of a marginalized group that disrupts power relations and produces moments and spaces of belonging. The youth are not trying to dominate public space, but, intentionally or unintentionally, aim to shift normative standards. MJD represents one place where they can do this with less cost and risk involved compared to other places. It is a serious game, where the (consciously or unconsciously) selected tactics must be understood as molded by several constraints, including gender, age, and internal group culture. In their efforts to challenge their Otherness, the youth restate their identities as Muslim women defined by a specific faith community. This risks creating a Self that is self-scrutinizing and self-disciplining. Taking up a position through affirming their identity as Muslim and struggling to modify or trouble the representation of that identity also risks situating them within other calculations of power and knowledge, which I discuss further in the next two chapters. 